lar. To then presume that infertility is the explanation for the lack of success of autopolyploids is to ignore the fact that many allopolyploids have also to overcome, and do, a barrier of sterility even more extreme than that of autos, albeit at the diploid level.

The success of this book will ultimately be judged by generations of students, but already it seems likely to be assured. The contribution which it makes can scarcely be said to startle or surprise, rather will it interest and satisfy, both the students for whom it is intended and others of more advanced levels of learning. K. Jones

\section{VASCULAR PLANTS OF EUROPE}

\section{Flora Europaea}

Edited by T. G. Tutin, V. H. Heywood, N. A. Burges, D. H. Valentine, S. M. Walters and D. A. Webb, with the assistance of P. W. Ball and A. O. Chater. Vol. 1: Lycopodiaceae to Plantanaceae. Pp. xxxii $+464+5$ maps. (Cambridge: At the University Press, 1964.) $84 s$.

HE publication of this volume (the first of four) means a most remarkable event to all biologists. To the layman and perhaps also to numerous biologists it may be a great surprise that no such work existed earlier. It is true that at the beginning of scientific botanical taxonomy the number of known species was so small that it was possible to publish works enumerating and describing them all. In his Species Plantarum (first ed., 1753), Linnaeus listed about 6,000 species in all, about 5,400 phanerogams and about 600 cryptogams. He believed the flora (and the fauna) of the tropics to be rather uniform and estimated the total number of plant species (of all groups) to be about 10,000. How wrong he was! The number grew rapidly and steadily through expeditions to various parts of the world. The microscope opened new worlds among the cryptogams. It became impossible to embrace the whole world in one Flora, and also other kinds of specialization became necessary. Besides phanero(ramists (and pteridologists) there came bryologists, phycologists, mycologists and lichenologists. It has nowadays almost become a convention that a Flora without any $\therefore$ pecifying attribute means one treating only phanerogams or vascular plants (that is, phanerogams + pteridophytes). The Flora Europaea is no exception, for it is no complete Flora but one restricted to vascular plants.

Even the relatively poor phanerogamic flora of Europe exceeds numerically the 10,000 species which Linnaeus thought to represent the final and total sum of all plant species. The total number of known species of phanerogams alone is to-day judged to approach 250,000 . Their ínal number cannot be estimated with any certainty as yet. In recent years the number of new species proposed syems to be on the decline, which may indicate that the stock of unknown species is now becoming exhausted. As to the European phanerogamic flora there remain certainly rather few species to be detected as new to science (or as new to Europe).

Why have we not had a comprehensive Flora of Europoan vascular plants much earlier? The main reason is that floristic (and faunistic) studies have in the past mostly been restricted geographically by political or even provincial boundaries. A positive merit of such restricted areas is that the making of inventories can be more thorough and lead to relative completeness within reasonable time. But there are also negative merits. The limits of distribution of plants (and animals) do not follow ndministrative boundaries. Even where there has been no 'iron curtain' scientific contacts and field studies across the boundaries have been much too scarce, and so it may happon that the same plant is identified differently in different countries and, vice versa, that different species pass under the same name in different countries. Moreover, the full amplitude of intraspecific variation and the sterility bar- riers of a species cannot be elucidated without following it throughout its whole area.

Most European countries possess Floras of their own, often modern and good ones. There are also Floras of a more regional character, for example, those treating two or more of the Nordic countries. The most pretentious Synopsis der Mitteleuropäischen Flora, started in 1896 by Ascherson and Graebner, has remained an unfinished work, but Hegi's magnificent Illustrierte Flora von Mitteleuropa, begun in 1908, runs now into its second edition. The eastern part of Europe is included in the gigantic Flora URSS (30 volumes, 1934-64).

In the 1940's the German W. Rothmaler projected a F'lora Europaea, which was to cover not only Europe but also the Caucasus, Transjordan and the parts of North Africa with Mediterranean flora. Post-wartime conditions were, however, too unfavourable for the realization of his project. On British initiative the question was discussed at the eighth International Botanical Congress (Paris, 1954) and shortly afterwards a committee was formed in Britain with T. G. Tutin (Leicester) as the chairman and V. H. Heywood (Liverpool) as the secretary. With enthusiasm they went to work. They gained support from all parts of Europe and financial aid from various sources, especially the D.S.I.R. Editors for the different families, regional advisers for the different countries and contributors were appointed. It was soon realized that the inclusion of North Africa would mean a disproportionately large amount of work, and so Europe was taken in its traditional sense. It seems queer, however, that Novaya Zemlya is oxcluded.

The editors' intention has been to produce a concise and complete Flora in the shortest possible time instead of aiming at the solution of all problems by meticulous monographic studies. The first volume was ready in 1964, and it is planned to complete the Flora over the next eight years.

The first volume treats the pteridophytes, the gymnosperms and part of the dicotyledons (Salicales-part of Rosales). Among the larger families may be mentioned Caryophyllaceae, Ranunculaceae, Cruciferae and Saxifragaceae. The largest genera are Silene (I66 species), Ranunculus (131 spp.), Saxifraga (123 spp.) and Dianthus (121 spp.). It follows from the aim of the work that the treatment cannot be uniform. This seems to be the case especially with the higher taxa. The delimitation of families and genera is sometimes hypermodern but mostly conservative; the generic concept is sometimes wide but mostly rather narrow. Huperzia, Lepidotis and Diphasium are thus segregated from Lycopodium, Consolida from Delphinium, Hepatica and Pulsatilla from Anemone, and Jovibarba from Sempervivum. The species concopt is, on the whole, moderately narrow. Subspecies are included but as a rule not taxa of lower rank. In some cases rather local races (especially some from the British Isles) have beon treated as sub-species; in numerous other cases such are discussed shortly without being given a definite taxonomic rank. The descriptions of the taxa of all ranks are clear and concise. There are keys not only to gonera, species and sub-specios but also to the families, which is a most unusual feature. I have not as yet tried to use the keys, but they look reliable. I have looked up all the Nordic plants and found no serious errors or omissions but a few debatable points and several interesting suggestions which deserve careful consideration. For less-known parts of Europe the volume contains a wealth of new information. In all parts of Europe it will certainly stimulate further research along different lines, as it gives an excellent review of tho present state of our knowledge and makes the results of previous studies easily available. Last but not least, it will be the indispensable tool for everybody wishing to name a European plant from outside his own country. The next three volumes are eagerly awaited. All engaged in the project are to be congratulated on this first volume. J. A. NANNFELDT 